\title{
Restaurant Location and Price Fairness as Key Determinants of Brand Equity: A Study on Fast Food Restaurant Industry
}

\author{
Jalal Hanaysha \\ Senior Lecturer, Faculty of Business and Management \\ DRB-HICOM University of Automotive Malaysia, 26607, Pekan, Pahang, Malaysia \\ E-mail: jalal.hanayshi@yahoo.com
}

Received: March 23, 2016 Accepted: April 10, 2016

doi:10.5296/ber.v6i1.9352 URL: http://dx.doi.org/10.5296/ber.v6i1.9352

\begin{abstract}
The main purpose of this study was to examine the direct effects of restaurant location and price fairness on brand equity in Malaysian market. The data were collected from several customers of international fast food restaurants in East Coast Malaysia. Convenience sampling methodology was utilized to obtain the responses from 384 customers during different times of data collection period. The collected data were coded into SPSS and analysed using structural equation modelling through AMOS 18. The findings indicated that restaurant location has significant positive effect on brand equity and its dimensions namely, brand image, brand loyalty, brand preference, and brand leadership. Moreover, it was found that price fairness has significant positive effect on overall brand equity and its dimensions. These results suggest that a restaurant location that is visible and accessible to customers seems to be an important factor in determining business success. Moreover, consumers tend to evaluate a restaurant brand based on price fairness that is matched with the quality of the offering. Therefore, this study urges policy makers in fast food restaurant industry to consider restaurant location and price fairness when designing their branding strategies.
\end{abstract}

Keywords: Brand equity, Restaurant location, Price fairness, Restaurant industry

\section{Introduction}

Brand equity has noticeably been viewed in the literature as one of the most important research topics in marketing over the past few years. There are various views being proposed towards brand equity in the marketing literature. Certain scholars conceptualized brand equity from a financial perspective, whereas others conceptualized it from the perspective of 
customers (Rios \& Riquelme, 2010). However, this study focuses only on conceptualizing and measuring brand equity from customer's perspective. This is because the evaluation of customers is deemed to be very important for an organization's success and sustainability. Keller (1993) described brand equity from customer's viewpoint as the differential impact of brand knowledge on the responses of customer toward the products or services of a particular brand. Brands that enjoy high equity receive favourable customer responses on their products or services as compared to those of an unknown brand (Keller, 1993). Pinar, Trapp, Girard, and Boyt (2014) also highlighted that the main purpose of setting branding strategies is to create high brand equity, and this is largely influenced by what their customers have learned, experienced, and heard about the brand.

Previous researches indicated that brand equity can be built and reinforced through different marketing factors according to the nature of industry or context of business. For example, restaurant location and price fairness have been considered to be very important in restaurant industry. Li, Ding, Deng, Jiang, and Liu (2015) found that location as a branding strategy had significant positive impact on market performance. Parsa, Self, Njite, and King (2005) also demonstrated that the success or failure of a restaurant can largely be affected by its physical location. The authors illustrated that accessibility and visibility of a restaurant are significant factors that explain its convenience and the strategic importance of the location. Similarly, price fairness is another important marketing factor that can be used to influence consumer's purchase decision and overall evaluation of a brand. Certain scholars reported that perceived price fairness has a significant positive effect on customer satisfaction and loyalty (Al-Msallam, 2015; Bassey, 2014; Beristain \& Zorrilla, 2011). However, despite the importance of restaurant location and price fairness in affecting brand loyalty and satisfaction, there are limited studies that examined their effects on brand equity.

Past literature also reveals that a vast amount of research has been conducted to understand how brand equity can be created in the package industry, but little is known about how it can be built and measured in the service industries. In other words, the importance of brand equity in the service industry in terms of marketing and business management has been addressed recently by both academics and practitioners, but the research of brand equity on the fast food restaurant industry in Malaysian context is still sparse and requires more attention. Moreover, there are limited studies that used brand preference and brand leadership as key components of brand equity. Therefore, this study is designed to examine the effects of restaurant location and price fairness on brand equity of fast food restaurant industry in Malaysia. Brand equity in this study consists of brand loyalty, brand image, brand preference, and brand leadership. The next sections start with a breif review of literature on the variables followed by methodology and analysis of results, then discussion and conclusion are presented.

\section{Literature Review}

\subsection{Brand Equity}

Brand equity was described in the literature as the incremental value supplemented to a product through its brand name (Farquhar, 1989). Aaker (1991, p.15) also defined brand 
equity as "a set of brand assets and liabilities linked to a brand, its name and symbol that add to or subtract from the value provided by a product or service to a firm and/or to that firms' customers". According to Keller (2003), a brand's power lies in consumers' minds and is enriched as a result of what they have learned or experienced about it over time. Keller (1993) defined customer-based brand equity as "the differential effect that brand knowledge has on consumers' responses to the marketing of that brand". Further contribution to brand equity was provided by Christodoulides, et al. (2006) who described it as the knowledge, perceptions, and attitudes of customers towards a brand which enable it to differentiate itself from competitors and get a competitive advantage over them. From a behavioural perspective, brand equity provides a company with competitive advantages to create points of differentiation and charge premium prices (Aaker, 1991).

Different researchers have suggested and measured brand equity sources in different ways. For instance, Aaker (1991) proposed the following dimensions to measure brand equity: brand awareness, brand associations, perceived quality, brand loyalty, and other properiety assets. On the other hand, Srivastava and Shocker (1991) regarded brand equity as a concept that consists of two elements - brand strength and brand value. According to Keller (1993), customer-based brand equity refers to "the differential effect that brand knowledge has on consumer responses to the marketing of a brand". He explained that brand knowledge includes brand awareness and brand image. Similarly, Lassar, Mittal, and Sharma (1995) conceptualized brand equity based on five elements; social image, brand value, brand performance, trustworthiness, and attachment. Aaker (1996) proposed brand leadership as a key component of brand equity, but only few studies contributed to this dimension. Oh and Pizam (2008) also suggested brand preference as key source of brand equity. However, this study aims to contribute to brand equity theory by incorporating brand image, brand loyalty, brand preference, and brand leadership as the key elements of brand equity.

Prior research described brand loyalty as the commitment of consumers to repurchase or keep using the products or services of a brand on the long-term, and this can be demonstrated by positive behaviors, such as positive word of mouth (Dick \& Basu, 1994). Brand image was defined by Hanaysha and Hilman (2015) as the overall impression of consumers' toward a brand. Favourable brand image leads to favourable purchase behaviour, while negative brand image results in dissatisfaction of customers and negative word of mouth. Moreover, brand preference refers to the willingness of consumers to choose a particular brand in presence of its competitors due to certain associations held in their memories. Finally, brand leadership refers to the ability of a brand to continually achieve excellence and innovate in a particular segment or industry through sufficient groupings of trend setting and brand positioning (Aaker \& Joachimsthaler, 2000). Miller and Mills (2011) also conceptualized brand leadership as the view of consumers toward a brand in terms of accepting that it is highly successful, visionary and is up-to-date with the latest developments.

\subsection{Restaurant Location}

Parsa, Gregory, and Terry (2010) illustrated that the choice of location is a very important factor that can affect the success or failure of a restaurant. They added that the success of a 
location is revealed through the physical site and its demographic surroundings. In other words, a good location is one that takes into consideration the geographic, demographic, and psychographic factors, and any changes in these factors could have significant influence on the degree of location attractiveness. Melia (2010) also demonstrated that location infrastructure quality should be benchmarked and measured against key competitors in order to obtain sustainable competitive advantage and enhance brand performance. For instance, a good location of a restaurant which provides several services to customers such as sufficient parking, eases of access, or situated near to city provides its brand with competitive advantage over those which their locations cannot provide such services.

The location in which a company operates its business is a key determinant of future success. For instance, a strategic location of a restaurant and its ability to distinguish itself from its competitors can enable it to ensure long-term survival (Parsa et al., 2005). While a restaurant can take advantage of close proximity to rivalry and restaurants are often situated in clusters to attract more customers, as in a "restaurant row," an operation might find itself in a group of restaurants within which it will face intense competition. According to Love (1972), location is one of the main factors behind successful fast food operations. The authors added that without having a good location, expert management and food quality may not be able to overcome the challenges of operation. Additionally, site location has become very important as markets reached a level of saturation. For this reason, it is a risk if restaurant management over-stress the significance of location in the operations of fast food industry. Past literature documented some of the key characteristics of a good location of fast food restaurant such as: site accessibility, size, population in the area, degree of competition, and economic condition.

Past studies reported that the choice of location has positive effect on brand equity. For instance, Wang, Tran, and Nguyen (2014) found that restaurant's location has positive effect on brand loyalty; considered a dimension of brand equity. Azim, Shah, Mehmood, Mehmood, and Bagram (2014) also established that location plays an important role in customers' preferences while selecting a restaurant. From the literature review, it was also observed that a strategic location that is visible and situated in an area which has large number of population acts as one of the key indicators of brand success. By looking at leading brands, it is obvious that they choose the best places to operate their businesses based on higher number of population and economic conditions. This strategy enabled them to attract larger number of customers and build strong brand equity. Based on this discussion, the following hypotheses are proposed:

H1: Restaurant location has positive effect on brand loyalty.

H2: Restaurant location positive effect on brand image.

H3: Restaurant location positive effect on brand preference.

H4: Restaurant location has positive effect on brand leadership.

H5: Restaurant location has positive effect on overall brand equity.

\subsection{Price Fairness}

Price has been considered as one of the foremost important factors that influence the behaviour of both firms and customers. As firms put high efforts to enhance their profits 
typically based on the price of their products or services, consumers tend to search for the best priced goods and services that will offer them maximum benefits. Anderson, Fornell, and Lehmann (1994) stressed on price as a key factor for affecting customer satisfaction, because customers usually think of the price whenever they assess the value of an acquired product or service. Past literature reported that consumers' perceived fairness of price has a main effect on their purchasing choices (Sinha \& Batra, 1999; Kahneman, Knetsch \& Thaler, 1986). According to Xia, Monroe, and Cox (2004), price fairness refers to the assessments of consumers of whether the prices for the products or services of a specific brand are reasonable, satisfactory or justifiable. The authors further indicated that price fairness evaluations encompass a comparison of the price with a certain standard, reference, or norm. As the evaluations of a price are based on a comparison with the products or service of other competitors, the perceptions of price fairness are aroused by price comparisons (Xia \& Monroe, 2010).

As noted in the literature, consumers tend to rely on some sort of reference price to assess whether a price is fair or not before making any purchase decision. That is, consumers are likely to form benchmarks or depend on reference prices in several ways such as recalling earlier transactions, detecting competitor prices, understanding the costs of seller, or by noticing the prices paid by other customers (Briesch, Krishnamurthi, Mazumdar, \& Raj, 1997). Overall, consumers tend to rely on several reference points before making decision to purchase, and this includes past prices, competitor prices, and cost of goods sold when assuming price fairness to make comparisons between different brands (Bolton Warlop, \& Alba, 2003). According to Campbell (1999), price fairness is a very important factor to be considered, because it can affect brand image, and thus, perceived price unfairness may result in negative consequences such as consumers' switching to other competitors and negative word of mouth.

Prior research found that price fairness had significant positive effect on brand equity and its elements (Al-Msallam, 2015; Beristain \& Zorrilla, 2011; Li \& Chaipoopirutana, 2015). Bassey (2014) also found that perceived price fairness had a significant influence on customer satisfaction and loyalty. Similarly, Anderson et al (1994) regarded price as an important factor for building satisfaction, and confirmed that consumers tend to evaluate the value of a product or service based on the actual price. Empirical researches also revealed that perceived price fairness directly affects customers' overall satisfaction and post-purchase behavior (Rothenberger, 2015; Wang, Potoglou, Orford, \& Gong, 2015). Therefore, providing a quality offering at reasonable price can help a brand to enhance its equity and obtain competitive advantages over other rivals. This offering will be a reason for consumers to select a certain brand over another. Based on the above discussion, the following hypotheses are presented:

H6: Price fairness has positive effect on brand loyalty.

H7: Price fairness has positive effect on brand image.

H8: Price fairness has positive effect on brand preference. 
H9: Price fairness has positive effect on brand leadership.

H10: Price fairness has positive effect on overall brand equity.

\section{Methodology}

This study was designed to test the effects of restaurant location and price fairness on brand equity in Malaysian market. Quantitative research approach is best suited to accomplish this objective and reach at conclusions. By referring to previous studies in the similar field, it can be observed that a survey instrument is regarded as the appropriate strategy for evaluating consumers' responses. The designed questionnaire was distributed on 384 respondents who are deemed to be real customers of popular international fast food restaurants in East Coast region of Malaysia. Survey instrument is considered to be the relevant strategy for collecting consumer data. During data collection, convenience sampling technique was employed in order to make sure that the desired sample size can be obtained. The respondents were approached at different times during data collection period and at different places in the region. This procedure was done in order to ensure the heterogeneity of respondents and minimize the possibilities of response bias. Due to the limitation of time and financial constraint, the survey was distributed on the respondents within the selected geographical area. Moreover, by looking at past literature, it can be observed that there are limited studies that have been conducted on this topic in this part of Malaysia.

To collect the data, a questionnaire was designed by adapting the measurement scales from previous studies. The scales chosen were because they had an acceptable reliability with Cronbach's alpha value of more than 0.7 . For instance, restaurant location was measured in terms of five-item scale being taken from Minai and Lucky (2011). A four-item scale was used to measure price fairness and it was adapted from the study of Hassan, Hassan, Nawaz, and Aksel (2013). In order to measure brand equity, four dimensions were combined together to represent this concept, and each dimension was measured using a set of items. Specifically, brand loyalty was measured using four items being taken from Gil et al. (2007), and Hameed (2013). To measure brand image, this study adapted a five-item scale from Jin et al. (2012), and Park (2009). Brand preference on the other hand was measured using four items being adapted from Sirgy (1997). Finally, five items were used to measure brand leadership, and the items were taken from the study of Aaker (1996), Hanaysha and Hilman (2015). All items were measured on five-point Likert scale ranging from $1=$ "strongly disagree" to $5=$ "strongly agree".

\section{Analysis of Results}

As stated above, 384 questionnaires were distributed on the respondents to collect the relevant data; however, only 293 questionnaires were filled and returned back. Based on the analysis of demographic data, it was found that $33.1 \%$ of the respondents are male, where $66.9 \%$ are female. The analysis of respondents' profile also showed that $19.4 \%$ are in the age category of 16 to 25 years, and 53.2\% are aged between 26 and 35 years. Those who fall in the age group of 36 to 45 years represented $20.5 \%$ of total response, while, $6.9 \%$ are aged from 46 years old and above. On income profile, $16.3 \%$ of the respondents get a monthly 
salary of less than RM500, 6.8\% receive monthly income in the range of RM500 to RM1000. Last but not least, those who receive a monthly income in the range of RM1000 to RM3000 accounted for $21.2 \%$ of overall response, and $55.7 \%$ obtain an income of more than RM3000 per month. Based on these findings, it can be said that the demographic composition of respondents is a representative sample of whole Malaysia because the data was obtained from different age groups and both genders. It can also be seen that the majority of respondents are female who were more willing to participate in answering the survey.

As with every survey research, testing the reliability of measures is important. Therefore, this study relied on SPSS 19 to calculate the reliability of all constructs using Cronbach's alpha procedure. Overall, the results supported the assumptions of reliability and internal consistency among the items of each construct. For instance, restaurant location and price fairness were reported at acceptable Cronbach's alpha values of 0.620 and 0.839 respectively. Similarly, the dimensions of brand equity yielded reasonable reliability with Cronbach's alpha values of more than 0.7 ; brand loyalty $(0.852)$, brand image $(0.826)$, brand preference (0.891), and brand leadership (0.780). The assumptions of existing acceptable reliability among all constructs were confirmed using composite reliability by calculating it through Microsoft Excel. The findings concluded that all values exceeded 0.70 .

Moreover, data screening was done for the purpose of further analysis on AMOS. Then, confirmatory factor analysis (CFA) was conducted using the measurement model in order to confirm that each set of items that are designed to measure a certain construct are in fact measuring it. The findings showed the factor loadings of remaining items are registered at 0.50 and above, and this supports the assumptions of convergent validity. The analysis on measurement model also revealed that the data is free from Multicollinearity issue as the correlation between any two constructs was below than 0.90 according to the suggestions of Tabachnick and Fidell (2001). Additionally, the structural model was drawn after achieving good fit for the measurmeent model. Overall, the structural model achieved a good fit to the current data as Chi-square $\left(\chi^{2}\right)$ is registered at $359.441(\mathrm{p}=0.000)$. Other fit indices were also used to ensure goodness of model fit; Goodness of Fit index (GFI) $=0.846$; Average Goodness of Fit index $(\mathrm{AGFI})=0.818$; Comparative Fit Index $(\mathrm{CFI})=0.932$, and Root Mean Square Error of Approximation (RMSEA) $=0.073$. These results indicate that the structural model adequately fit the data (Hair, Black, Babin, \& Anderson, 2010).

The hypotheses that are stated above were tested using regression table which was extracted from the outputs of structural model. As shown in Table 1, the results indicate that restaurant location has significant positive impact on brand loyalty $(\beta=0.293$, t-value $=3.777, \mathrm{p}<$ $0.05)$, this means that $\mathrm{H} 1$ is confirmed. The effect of restaurant location on brand image also appears positive and statistically significant at $p=<0.001(\beta=0.431$, $t$-value $=3.056)$, thus, $\mathrm{H} 2$ is supported. Furthermore, the results indicated that restaurant location has significant positive effect on brand preference $(\beta=0.352$, t-value $=3.955, \mathrm{p}<0.05)$, hence, $\mathrm{H} 3$ is accepted. The findings of this study also reveal that restaurant location has a significant positive impact on brand leadership $(\beta=0.752$, t-value $=3.869, \mathrm{p}<0.05)$, therefore, H4 is confirmed. Additionally, the findings confirmed that restaurant location has significant positive impact on overall brand equity $(\beta=0.623$, t-value $=5.321, \mathrm{p}<0.05)$, which means 
that $\mathrm{H} 5$ is accepted.

The hypotheses relating to the effect of price fairness on brand equity and its dimensions were also examined. The findings indicated that price fairness has significant positive influence on brand loyalty $(\beta=0.153$, $\mathrm{t}$-value $=3.271, \mathrm{p}<0.05)$, and this supports H6. The direct effect of price fairness on brand image is also positive and statistically significant $(\beta=$ 0.356 , $\mathrm{t}$-value $=4.712, \mathrm{p}<0.05$ ), therefore, $\mathrm{H} 7$ is supported, Additionally, $\mathrm{H} 8$ which stated that price fairness has positive effect on brand preference is supported $(\beta=0.439$, $t$-value $=$ $3.585, \mathrm{p}<0.05)$. The findings also support the positive effect of price fairness on brand leadership $(\beta=0.419$, t-value $=2.025, \mathrm{p}<0.05)$, and thus, H9 is confirmed. Finally, the findings of this study supported $\mathrm{H} 10$ which postulated that price fairness has positive effect on brand equity $(\beta=0.421$, $\mathrm{t}$-value $=3.615, \mathrm{p}<0.05)$. In sum, restaurant location and price fairness contribute by $45 \%$ of total variance in overall brand equity.

Table 1. Results of Hypotheses

\begin{tabular}{|c|c|c|c|c|c|c|c|}
\hline & \multicolumn{3}{|l|}{ Hypotheses } & Std. $\beta$ & S.E. & C.R. & $\mathrm{P}$ \\
\hline H1: & Restaurant Location & $\rightarrow$ & Brand Loyalty & 0.293 & 0.501 & 3.777 & $* * *$ \\
\hline $\mathrm{H} 2$ : & Restaurant Location & $\rightarrow$ & Brand Image & 0.431 & 0.476 & 4.056 & *** \\
\hline H3: & Restaurant Location & $\rightarrow$ & Brand Preference & 0.352 & 0.595 & 3.955 & $* * *$ \\
\hline $\mathrm{H} 4$ : & Restaurant Location & $\rightarrow$ & Brand Leadership & 0.752 & 0.453 & 3.869 & $* * *$ \\
\hline H5: & Restaurant Location & $\rightarrow$ & Overall BE & 0.623 & 0.117 & 5.321 & $* * *$ \\
\hline H6: & Price Fairness & $\rightarrow$ & Brand Loyalty & 0.153 & 0.216 & 3.271 & $* * *$ \\
\hline H7: & Price Fairness & $\rightarrow$ & Brand Image & 0.356 & 0.208 & 4.712 & $* * *$ \\
\hline H8: & Price Fairness & $\rightarrow$ & Brand Preference & 0.439 & 0.277 & 3.585 & $* * *$ \\
\hline H9: & Price Fairness & $\rightarrow$ & Brand Leadership & 0.419 & 0.207 & 2.025 & 0.043 \\
\hline H10: & Price Fairness & $\rightarrow$ & Overall BE & 0.421 & 0.275 & 3.615 & $* * *$ \\
\hline
\end{tabular}

\section{Discussion and Conclusion}

This paper was primarily designed to investigate the direct effects of restaurant location and price fairness on brand equity in Malaysian market. The findings indicated that restaurant location has significant positive effect on brand loyalty and brand image, and this is consistent with previous researches (Wang et al., 2014). Therefore, in order to be successful in creating brand loyalty and favourable image in consumers' minds, it is suggested that the management in restaurant industry should make wise decisions for locating their business by choosing strategic places which have access to large number of customers. Additionally, consumers are likely to develop positive impression about the capabilities and strengths of brands which manage to secure places for their branches at busy areas. By making it easy for customers to reach a restaurant brand, they will ultimately develop better repurchase intentions if they had positive experiences.

Moreover, the outcomes of this paper revealed that restaurant location has significant positive effect on brand preference, brand leadership, and overall brand equity. Zheng (2011) found that restaurant location has positive effect on consumer's choice. Parsa et al. (2010) also 
reported that the choice of location for operating a restaurant has significant effect on its success or failure. The authors specified that the success of a location depends on several factors such as physical site and surrounding demographics. Therefore, a convenient location is very important factor that can influence consumers' preferences in selecting a restaurant. Moreover, global restaurants tend to select strategic locations for opening their branches by taking into consideration several factors such as: visibility, population, economic conditions, and accessibility. Such factors are found to be very important in influencing consumers' purchase decisions that would ultimately result in higher brand equity.

The findings of this study also confirmed the direct effect of price fairness on brand loyalty and brand image. A number of scholars reported similar conclusions suggesting that price fairness had positive impact on brand loyalty and brand image (Al-Msallam, 2015; Campbell, 1999; Li \& Chaipoopirutana, 2015). Greater support was reported in the study of Bassey (2014) who found that perceived price fairness had a significant positive influence on the satisfaction and loyalty of customers. Beristain and Zorrilla (2011) also reported that when consumers perceive the price of company's products or services as affordable or relatively acceptable, they tend to develop a positive loyalty and associations toward the brand. Therefore, price fairness perception plays an important role in influencing customers' post-purchase behaviour, including positive or negative word of mouth and repurchase behaviour (Wang et al., 2015).

Finally, this study concludes that price fairness is one of the key drivers for brand preference, brand leadership, and overall brand equity, and this was supported by certain previous researches (Kabadayi, Aygun, \& Cipli, 2007; Rajh, 2006). Therefore, pricing strategy can have a positive impact on brand equity, because consumers tend to form purchase decisions after careful evaluation of the value which they get from the purchased product or service. Besides, customers tend to make comparisons between different brands in terms of the price and quality of the offering. Such comparisons will help them to determine which brand to choose after considering the costs and benefits of purchase process. The practical implication from the above results suggests that restaurant brands should strive to deliver competitive products and services at fair prices if they want to succeed and enhance their brand equity. It is believed that customers would prefer to select brands that provide higher value for them.

This paper has some limitations that should be addressed in future researches. For instance, the data was collected only from East Coast Malaysia; therefore, future studies may examine the variables using larger sample sizes with wider coverage of entire Malaysia rather than focusing only on East Coast Malaysia. Second, only two factors were examined in this study as key antecedents of brand equity; hence, future researches can test other factors such as ambience and diversity of offerings. Third, cross sectional survey was employed for collecting the data; therefore, future research may rely on longitudinal data to further strengthen the results and reach at better conclusions. Finally, this study is expected to provide a platform for future researches to re-examine the effects of restaurant location and price fairness on brand equity as previous studies of this nature are very limited. 


\section{References}

Aaker, D. A. (1991). Managing Brand Equity, Free Press, NY.

Aaker, D. A. (1996). Measuring brand equity across products and markets. California Management Review, 38(3), 102-120. http://dx.doi.org/10.2307/41165845

Aaker, D. A., \& Joachimsthaler, E. (2000). Brand Leadership. New York: Free Press.

Al-Msallam, S. (2015). The relationship between customer satisfaction and customer loyalty in the banking sector in Syria. Journal of Marketing and Consumer Research, 7, 27, 34.

Anderson, E. W., Fornell, C., \& Lehmann, D. R. (1994). Customer satisfaction, market share, and profitability: Findings from Sweden. The Journal of Marketing, 53-66. http://dx.doi.org/10.2307/1252310

Azim, A., Shah, N. A., Mehmood, Z., Mehmood, S., \& Bagram, M. M. M. (2014). Factors Effecting the Customers Selection of Restaurants in Pakistan. International Review of Management and Business Research, 3(2), 1003.

Bassey, F. O. (2014). The Effect of Perceived Price Fairness on Customer Satisfaction and Loyalty (Master dissertation, Eastern Mediterranean University).

Beristain, J. J., \& Zorrilla, P. (2011). The relationship between store image and store brand equity: A conceptual framework and evidence from hypermarkets. Journal of Retailing and Consumer Services, 18(6), 562-574. http://dx.doi.org/10.1016/j.jretconser.2011.08.005

Bolton, L. E., Warlop, L., \& Alba, J. W. (2003). Consumer perceptions of price (un) fairness. Journal of Consumer Research, 29(4), 474-491. http://dx.doi.org/10.1086/346244

Briesch, R. A., Krishnamurthi, L., Mazumdar, T., \& Raj, S. P. (1997). A comparative analysis of reference price models. Journal of Consumer Research, 24(2), 202-214. http://dx.doi.org/10.1086/209505

Campbell, M. C. (1999). Perceptions of price unfairness: antecedents and consequences. Journal of Marketing Research, 187-199. http://dx.doi.org/10.2307/3152092

Christodoulides, G., De Chernatony, L., Furrer, O., Shiu, E., \& Abimbola, T. (2006). Conceptualising and measuring the equity of online brands. Journal of Marketing Management, 22(7-8), 799-825. http://dx.doi.org/10.1362/026725706778612149

Dick, A. S., \& Basu, K. (1994). Customer loyalty: toward an integrated conceptual framework. Journal of the Academy of Marketing Science, 22(2), 99-113. http://dx.doi.org/10.1177/0092070394222001

Farquhar, P. H. (1989). Managing brand equity. Marketing research, 1(3), 24-33.

Gil, R.B., Andrés, E. F., \& Salinas, E. M. (2007). Family as a source of consumer-based brand equity. Journal of Product \& Brand Management, 16(3), 188-199. http://dx.doi.org/10.1108/10610420710751564 
Hair, J., Black, W. C., Babin, B. J., \& Anderson, R. E. (2010). Multivariate data analysis (7th edition). Upper saddle River, New Jersey: Pearson Education International.

Hameed, F. (2013). The effect of advertising spending on brand loyalty mediated by store image, perceived quality and customer satisfaction: A case of hypermarkets. Asian Journal of Business Management, 5(1), 181-192.

Hanaysha, J., \& Hilman, H. (2015). Advertising and country of origin as key success factors for creating sustainable brand equity. Journal of Asian Business Strategy, 5(7), 141-152.

Hassan, M., Hassan, S., Nawaz, M. S., \& Aksel, I. (2013). Measuring customer satisfaction and loyalty through service fairness, service quality and price fairness perception: an empirical study of Pakistan Mobile telecommunication sector. Journal Science International-(Lahore), 25(04), 971-980.

Jin, N., Lee, S., \& Huffman, L. (2012). Impact of restaurant experience on brand image and customer loyalty: Moderating role of dining motivation. Journal of Travel \& Tourism Marketing, 29(6), 532-551. http://dx.doi.org/10.1080/10548408.2012.701552

Kabadayi, E. T., Aygun, I., \& Cipli, C. (2007). The effects of marketing mix strategies on brand equity: mobile phone sector. Journal of Global Strategic Management, 2, 74-81.

Kahneman, D., Knetsch, J. L., \& Thaler, R. (1986). Fairness as a constraint on profit seeking: Entitlements in the market. The American Economic Review, 728-741.

Keller, K. L. (1993). Conceptualizing, measuring, and managing customer-based brand equity. Journal of Marketing, 1-22. http://dx.doi.org/10.2307/1252054

Keller, K. L. (2003). Strategic brand management: Building, measuring and managing brand equity (second edition). New Jersey: Prentice Hall.

Lassar, W., Mittal, B., \& Sharma, A. (1995). Measuring customer-based brand equity. Journal of Consumer Marketing, 12(4), 11-19. http://dx.doi.org/10.1108/07363769510095270

Li, W., Ding, Y., Deng, D., Jiang, W., \& Liu, Z. (2015). Empirical analysis of the relationship between marketing strategies and marketing performance of agricultural science and technology enterprise. Proceedings of the Ninth International Conference on Management Science and Engineering Management, 1097-1107. http://dx.doi.org/10.1007/978-3-662-47241-5_93

Li, Z., \& Chaipoopirutana, S. (2015). The important factors that influence on building brand loyalty towards Chang'an car brand in Xi'an city, Shaanxi, China. Retrieved on 1 February, 2016 from: http://www.utccmbaonline.com/Journalsys/Upload_Arti/2015-02-02_12:26:21.pdf

Love, H. G. (1972). Fast food store location factors: A comparison with grocery store location factors. Journal of Food Distribution Research, 3(1), 40-43.

Melia, D. (2010). Critical Success Factors and Performance Management and Measurement: a Hospitality Context. Retrieved on 5 January, 2015 from: http://arrow.dit.ie/tfschmtcon/43/ 
Miller, K. W., \& Mills, M. K. (2012). Contributing clarity by examining brand luxury in the fashion market. Journal of Business Research, 65(10), 1471-1479. http://dx.doi.org/10.1016/j.jbusres.2011.10.013

Minai, M. S., \& Lucky, E. O. I. (2011). The moderating effect of location on small firm performance: Empirical evidence. International Journal of Business and Management, 6(10), 178-192.

Oh, H., \& Pizam, A. (2008). Handbook of hospitality marketing management. Routledge.

Park, S. H. (2009). The antecedents and consequences of brand image: Based on Keller's customer-based brand equity (Doctoral dissertation, The Ohio State University).

Parsa, H. G., Gregory, A., \& Terry, M. (2010). Why do restaurants fail? Part III: An analysis of macro and micro factors. Emerging Aspects Redefining Tourism and Hospitality, 1(1), $16-25$.

Parsa, H. G., Self, J. T., Njite, D., \& King, T. (2005). Why restaurants fail. Cornell Hotel and Restaurant Administration Quarterly, 46(3), 304-322. http://dx.doi.org/10.1177/0010880405275598

Pinar, M., Trapp, P., Girard, T., \& E. Boyt, T. (2014). University brand equity: an empirical investigation of its dimensions. International Journal of Educational Management, 28(6), 616-634. http://dx.doi.org/10.1108/ijem-04-2013-0051

Rajh, E. (2006). The effects of marketing mix elements on brand equity. Croatian Economic Survey, (8), 53-80.

Rios, R. E., \& Riquelme, H. E. (2010). Sources of brand equity for online companies. Journal of Research in Interactive Marketing, 4(3), 214-240. http://dx.doi.org/10.1108/17505931011070587

Rothenberger, S. (2015). Fairness through transparency: The influence of price transparency on consumer perceptions of price fairness. Working Papers CEB, 15.

Sinha, I., \& Batra, R. (1999).The effect of consumer price consciousness on private label purchase. International Journal of Research in Marketing, 16(3), 237-251. http://dx.doi.org/10.1016/S0167-8116(99)00013-0

Sirgy, M. J., Grewal, D., Mangleburg, T. F., Park, J. O., Chon, K. S., Claiborne, C. B., Johar, J. S., \& Berkman, H. (1997). Assessing the predictive validity of two methods of measuring self-image congruence. Journal of the Academy of Marketing Science, 25(3), 229-241. http://dx.doi.org/10.1177/0092070397253004

Srivastava, R. K., \& Shocker, A. D. (1991). Brand equity: a perspective on its meaning and measurement. Marketing Science Institute, Cambridge, MA.

Tabachnick, B. G., \& Fidell, L. S. (2001). Using multivariate analysis. California State University Northridge: Harper Collins College Publishers. 
Wang, L. W., Tran, T. T., \& Nguyen, N. T. (2014). Analyzing factors to improve service quality of local specialties restaurants: A Comparison with fast food restaurants in Southern Vietnam. Asian Economic and Financial Review, 4(11), 1592-1606.

Wang, Y., Potoglou, D., Orford, S., \& Gong, Y. (2015). Bus stop, property price and land value tax: A multilevel hedonic analysis with quantile calibration. Land Use Policy, 42, 381-391. http://dx.doi.org/10.1016/j.landusepol.2014.07.017

Xia, L., Monroe, K. B., \& Cox, J. L. (2004). The price is unfair! A conceptual framework of price fairness perceptions. Journal of Marketing, 68(4), 1-15. http://dx.doi.org/10.1509/jmkg.68.4.1.42733

Xia, L., \& Monroe, K. B. (2010). Is a good deal always fair? Examining the concepts of transaction value and price fairness. Journal of Economic Psychology, 31(6), 884-894. http://dx.doi.org/10.1016/j.joep.2010.07.001

Zheng, Y. (2011). A Study of some of the factors determining the choice of international restaurants by Bangkokians. AU-GSB e-JOURNAL, 4(1).

\section{Appendix}

Appendix 1. Measurement Scales of Constructs

\begin{tabular}{|c|c|c|}
\hline Code & Construct/ Items & $\begin{array}{l}\text { Factor } \\
\text { loadings }\end{array}$ \\
\hline & Restaurant Location $($ Cronbach's Alpha $=0.620)$ & \\
\hline LOC1 & This restaurant is located in the busy area. & 0.840 \\
\hline LOC2 & $\begin{array}{l}\text { The location of this restaurant is suitable in such a way that allows me to access it } \\
\text { easily. }\end{array}$ & 0.674 \\
\hline LOC3 & This restaurant is located in a clean area. & 0.761 \\
\hline LOC4 & $\begin{array}{l}\text { This restaurant is located in a convenient area in which the parking is available to } \\
\text { customers. }\end{array}$ & 0.884 \\
\hline \multirow[t]{2}{*}{ LOC5 } & The restaurant is located in a visible place making it easy for others to see it. & 0.741 \\
\hline & Price Fairness $($ Cronbach's Alpha $=0.839)$ & \\
\hline PF1 & This restaurant offers the best possible price plan that meets my needs & 0.684 \\
\hline $\mathrm{PF} 2$ & The food price charged by this restaurant is reasonable. & 0.895 \\
\hline PF3 & The costs in this restaurant seem appropriate for what I get. & 0.834 \\
\hline \multirow[t]{3}{*}{ PF4 } & $\begin{array}{l}\text { Overall, this restaurant provides superior pricing options compared to other service } \\
\text { providers. }\end{array}$ & 0.618 \\
\hline & Brand Equity Dimensions: & \\
\hline & a. $\quad$ Brand Image $($ Cronbach’s Alpha $=0.826)$ & \\
\hline BI1 & The brand of this restaurant has a fashionable and trendy image. & 0.649 \\
\hline $\mathrm{BI} 2$ & The brand of this restaurant has a reputation for quality. & 0.775 \\
\hline $\mathrm{BI} 3$ & The brand of this restaurant has unique features. & 0.617 \\
\hline BI4 & The brand of this restaurant provided me a better lifestyle. & 0.716 \\
\hline BI5 & The brand of this restaurant provides good value to its customers. & 0.752 \\
\hline
\end{tabular}




\begin{tabular}{|c|c|c|}
\hline & b. $\quad$ Brand Loyalty (Cronbach's Alpha $=0.852)$ & \\
\hline BL1 & I consider myself to be loyal to the brand of this restaurant. & 0.681 \\
\hline BL2 & I would continue to visit this restaurant even if its prices increase somewhat. & 0.748 \\
\hline BL3 & I say positive things about this restaurant to other people. & 0.834 \\
\hline \multirow[t]{2}{*}{ BL4 } & I recommended this restaurant to others. & 0.822 \\
\hline & c. $\quad$ Brand Preference (Cronbach's Alpha $=0.891)$ & \\
\hline BP1 & I like to go to this restaurant more than others. & 0.896 \\
\hline BP2 & I would buy from this restaurant frequently. & 0.730 \\
\hline BP3 & This restaurant is my preferred choice over others. & 0.880 \\
\hline \multirow[t]{2}{*}{ BP4 } & I would be inclined to buy from this restaurant brand over other brands. & 0.806 \\
\hline & d. Brand Leadership (Cronbach's Alpha $=0.780)$ & \\
\hline BLe1 & This restaurant brand is one of the leading brands in its category. & 0.764 \\
\hline BLe2 & This restaurant brand is growing in popularity. & 0.821 \\
\hline BLe3 & This restaurant brand provides good care to its customers. & 0.539 \\
\hline BLe4 & $\begin{array}{l}\text { This restaurant brand is one of the most widespread brands and can be found in } \\
\text { different places. }\end{array}$ & 0.646 \\
\hline BLe5 & The brand of this restaurant has many visitors every day. & 0.509 \\
\hline
\end{tabular}

\section{Copyright Disclaimer}

Copyright for this article is retained by the author(s), with first publication rights granted to the journal.

This is an open-access article distributed under the terms and conditions of the Creative Commons Attribution license (http://creativecommons.org/licenses/by/3.0/). 